Department of Human Anatomy, Oxford and St. Bartholomew's Hospital, London

D. F. Roberts and H. Lehmann

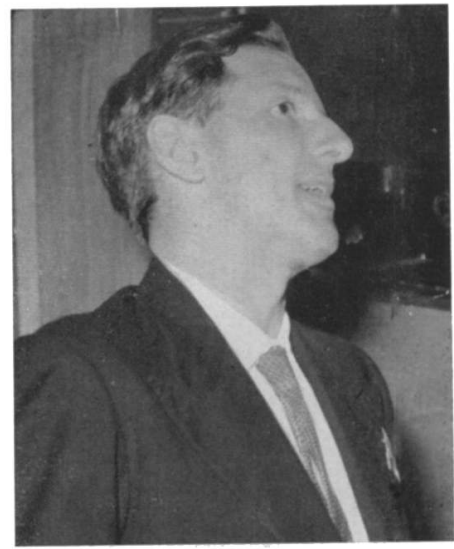

\title{
Preliminary Observations
}

\section{on Haemoglobin Gene Frequencies in the Lake Chad Region}

The peoples of the Lake Chad region who form the subject of this study are inhabitants of Bornu, today an administrative province of northeast Nigeria which includes the northern Cameroons, formerly one of the great empires of interior Africa. There were several reasons why this survey of abnormal haemoglobins was undertaken. It was an obvious consideration that nothing was known of their incidence in this area; indeed for the vast complicated ethnological patchwork that comprises the peoples of northern Nigeria there have been studied to date only general samples, predominantly Hausa. It should be regarded as a matter of urgency to ascertain gene frequencies in African peoples before their differences are completely obliterated with the breakdown of tribal patterns, and before the selection pressure differentials are readjusted with the arrival of modern medicine.

Another more cogent reason however lay in the historical information available for the area. Ancient tribal traditions are supplemented by the writings of early Muslim travellers and the written documents of the people themselves, and though many of the latter records were destroyed in the several invasions of Bornu, enough remain to enable the main outline of events over the last I, 200 years to be reconstructed. The story is of a succession of invasions and immigrations by peoples of different ethnic affinities, speaking different languages, possessing different customs, ways of life and outlook; the habitat into which they came is essentially uniform, a vast plain of scrub savana. It appeared of interest to enquire whether the demands of a uniform habitat had levelled out the genetic differences expected in peoples of such diverse 
origins, and if not to examine the extent to which such differences had been retained. The Kanouri, linguistically akin to the Teda of Tibesti, entered Bornu in a series of waves from Kanem in the $13^{\text {th }}$ and $14^{\text {th }}$ centuries, subjugating the earlier inhabitants. Kanouri is a name sometimes applied loosely to all Kanouri speaking inhabitants of Bornu but the present sample refers to those who call themselves Kanouri in contradistinction to other groups of the area, e.g. the Kwoyam and Kanembu. Today the Kanouri are town and village dwellers, whose economy is centred on agriculture. At the beginning of the I 7 th century the Shuwa Arabs began to appear in Bornu from the east, where they had been settled in Darfur and Wadai, and they merged with the Kanouri and other previous inhabitants. But in I8og, in response to an invitation from Shehu Laminu to help him drive the invading Fulani out of Bornu, a second wave of Shuwa tribes entered, were given lands and granted independence of Kanouri control, being ruled by their own sheikhs, and it is from these tribes that the present sample was drawn. They are much more dependent on pastoralism than the Kanouri, spending the wet season in their own small untidy villages and the dry season away at pasture, though a certain amount of cultivation is also done. Shehu Laminu at the same period also invited Kanembu tribes from the east of Lake Chad into Bornu to support him; many subsequently intermarried with the Kanouri, but the Bedduwai, perhaps by reason of their pastoral nomadism, have remained relatively unmixed and are still regarded as the purest of the Kanembu tribes. Although the Kanembu were at one time distinct from the Kanouri, being established in Kanem before the arrival there of the latter, they are of the same language group and are considered by some to be of common stock. The Wakura, one of the pagan tribes in the extreme southeast of the area, are representatives of the most recent movement into the Bornu plains, one that is still taking place, down from the mountains of the northern Cameroons. Traditionally, these pagan peoples moved into the mountains above Gwoza from the ranges to the south (Adamawa) and east (Mandara), at a period which study of their genealogies suggests was well over 4-50o years ago. Their mountain refuges served as protection in the early days against the continual slave raiding of the Mandara, and, from the early igth century until i922, against the exactions of the Fulani. It is therefore only within the last few decades that conditions have been sufficiently stable to attract a proportion of these pagans down from their terrace cultivations of the mountains to the easier farming in the plains. The Wakura today are established in the foothills and adjacent plains round the Zeledva spur, at the extreme northern tip of the Cameroons mountains.

Blood specimens were obtained from about Ioo apparently healthy individuals of each of these 4 peoples. Adult males only were represented in the Kanouri, Bedduwai, and Shuwa, but in view of the smallness of their settlements and consequent difficulty of sampling a number of females were included in the Wakura sample. Genealogical investigation ensured that close relatives were excluded and only those whose remembered ancestry included no intermixture with other peoples were examined. Sampling was based in the case of the Shuwa on the tribal and sectional structure, in the Wakura on the lineages, and in the Kanouri and Bedduwai on place 
of residence; the Kanouri sample covered I05 villages, while the 92 Bedduwai were from 63 different villages. The Shuwa sample was drawn from an area within a 30 mile radius east of Golumba, the Kanouri sample from villages between 20 and 60 miles northwest of Maiduguri, the area from which the Bedduwai were derived lay between 4.0 and Ioo miles northwest of Maiduguri, while the Wakura sample was obtained from their settlements in the plains round the foot of the Zeledva spur to the north of Gwoza. The specimens were sent by air to London, where they were analysed electrophoretically on paper strips in vertical electrophoresis tanks in runs of $14-18$ hour duration at i6o volts, using a buffer solution of $\mathrm{pH}$ 8.6.

\section{Results}

The results are set out in the Table; the gene frequencies were calculated by the addition method.

Haemoglobin Frequencies in Bornu Samples

\begin{tabular}{|c|c|c|c|c|c|c|c|c|c|c|}
\hline & \multirow[b]{2}{*}{ No. } & \multicolumn{3}{|c|}{ Phenotypes observed } & \multicolumn{3}{|c|}{ Phenotype Frequencies } & \multicolumn{3}{|c|}{ Gene Frequencies } \\
\hline & & AA & AS & $\mathrm{AC}$ & $\mathrm{AA}$ & AS & $\mathrm{AC}$ & $\mathrm{Hb} . \mathrm{A}$ & $\mathrm{S}$ & C \\
\hline Shuwa & 105 & 83 & 22 & - & $.79^{\mathrm{I}}$ & .210 & - & .895 & .105 & - \\
\hline Wakura & 104 & 75 & 23 & 6 & $.72 \mathrm{I}$ & $.22 \mathrm{I}$ & $.05^{8}$ & $.86 \mathrm{I}$ & . I I I & .029 \\
\hline Kanouri & I 6 & 79 & 37 & 一 & $.68 \mathrm{I}$ & .319 & 一 & $.84 \mathrm{I}$ & .160 & - \\
\hline Bedduwai & 92 & 62 & 30 & - & .674 & .326 & & .837 & .163 & \\
\hline
\end{tabular}

I. The abnormal haemoglobins observed were C and S. C only occurs amongst the pagan Wakura, though the samples are not sufficiently large to indicate whether it is in fact absent or present at trace frequencies in the other peoples. The sickle cell trait is present at high frequencies, in the Kanouri and Bedduwai higher than has hitherto been found in any other non-Bantu sample in Africa, though higher frequencies have been recorded in a few of the numerous Bantu samples available. When the association of malaria with the sickle cell trait was first pointed out ( $\mathrm{I}$ ), it seemed that high frequencies of the trait were observed where malaria is hyperendemic, low frequencies in malaria-free and epidemic zones. A number of studies have since shown $(3,4)$, that in endemic zones are to be found examples of peoples in whom the trait is either absent or present only at low frequency, explicable respectively on the hypotheses that the trait has not yet, or only recently, been introduced to the area. In Bornu the reverse situation occurs. The malarial pattern is epidemic; the survey was conducted during the dry season, and parasites were observed in only 20 individuals in a sample of $592(3.4 \%)$; yet the $\mathrm{S}$ incidence is high.

2. The absence of homozygous carriers of the abnormal haemoglobins is striking. With an overall incidence of I I 2 AS heterozygotes $(26.8 \%)$ out of a total sample of $4 \mathrm{I} 7$, one might have expected 7 or 8 SS homozygotes to occur, or if all survived to reproductive age 9 or Io. From the present sample it seems that, as has been noted 
elsewhere in Africa, $(2,6)$, in Bornu SS homozygotes are eliminated from the population before they reach adulthood, a wastage of $1.8 \%$ of all children born.

3. Despite the ethnic diversity of the peoples examined there are no significant differences in the observed frequencies of their abnormal haemoglobins, both when the 4 samples are compared simultaneously and when any two are considered. The more recent comers are not consistently lower in their $\mathrm{S}$ frequencies than the longer established Kanouri. Only when a contrast is made between on the one hand the Kanouri and Bedduwai grouped together (for which there may be some justification on grounds of similarity of language, area of former residence etc., though they differ in the frequencies of some of their bloodgroup genes), and on the other the Shuwa and Wakura grouped together (for which there is no ethnic justification, their only similarity lying in their relatively recent immigration to the Bornu plains) does a significant difference occur in the hb. S frequency.

As regards the similarity of the 4 samples, it is of course possible that these contain insufficient numbers for statistically significant differences in their haemoglobin frequencies to be demonstrated. Further work is in progress to test this possibility, and a total of over Iooo specimens are in process of examination. Secondly it may be suggested that extensive interbreeding of the different peoples since they entered Bornu, either with each other or with earlier inhabitants of their present territories, has obliterated initial differences in gene frequencies. This suggestion is untenable since, although some degree of intermixture has occurred, highly significant variations are detectable in the bloodgroup gene frequencies of these peoples (5). No figures are available for the frequencies of the haemoglobin genes in the areas from which these peoples migrated, but it appears likely that the Shuwa at least came from an area where $S$ was either very rare or absent. $A$ third possibility is that there has been a relatively rapid rate of change of hb gene frequency in these later comers. This last suggestion receives support from the consistently higher frequency of hb $\mathrm{S}$ observed in individuals under the age of about 40 as compared with the older individuals; the Kanouri also share this trend. Further examination of this age difference is obviously necessary, but if it is substantiated it would suggest that even for the Kanouri the process of obtaining a balance between the gene frequency and the environment is still incomplete, indicating a relatively recent appearance of the hb $\mathrm{S}$ gene in the area. There remains the difference between the Kanouri/Bedduwai and the Shuwa/Wakura to be explained. The hypothesis which seems to cover most satisfactorily all the findings may be tentatively stated as follows:

At some time prior to, though not very long before, the beginning of the igth century the hb S gene appeared in the Lake Chad region and increased in frequency, an increase shared by the Kanouri of Bornu and Kanembu to the east; the migration of the Bedduwai to Bornu hardly affected the trend in them, and this increase is still in progress in both peoples. The Shuwa and Wakura came from territories in which selection pressure for $\mathrm{hb} \mathrm{S}$ was less intense. At the time of their entry into Bornu the Shuwa possessed little $\mathrm{S}$, and during the last $15^{\circ}$ years its frequency has been, and is now being, modified towards that optimal for the Bornu plains. Similar modification 
is now occurring among the Wakura who, by reason of their geographical position, had a somewhat higher initial frequency of abnormal haemoglobins, so that the $S$ frequency observed among them is today similar to that in the Shuwa. In both it remains lower than in the Bedduwai/Kanouri since they have been exposed to the Ghad area selection pattern for a shorter period.

\section{References}

I. Allison, A. C.: Brit. Med. J., I954. 1, 290.

2. Lambotte-Legrand, J. \& C.: Ann. Soc. Belge. Med. Trop., 1955. 35, 47.

3. Livingstone, F. B.: Am. J. Human Genetics, 1958. 10, 33.

4. Roberts, D. F. \& Lehmann, H.: Brit. Med. J., I955. I, 5 I9.

5. Roberts, D. F., Ikin, E. \& Mourant, A. E.: In preparation.

6. Vandepitte, J. M.: Ann. Soc. Belge. Med. Trop., i $954 \cdot 34,501$. 